\title{
Groundwater Assessment by using Water Quality Index in Some Agricultural Expansion Areas in Sohag Governorate, Egypt
}

\author{
Abdel-Rahman A. Mustafa ${ }^{1}$ and Mahdy H. Hamed ${ }^{2}$
}

\begin{abstract}
The present study aims to assess groundwater quality for agriculture purposes using water quality index (WQI) in some agricultural Expansion areas at Sohag Governorate in Egypt. Forty seven (47) water samples were collected from different wells and analyzed. The parameters that define the water quality were recognized using Principal Component Analysis and Factor Analysis (PCA/FA). Hence electrical conductivity (EC), soluble sodium $\left(\mathrm{Na}^{+}\right)$, soluble chloride $\left(\mathrm{Cl}^{-}\right)$, and sodium adsorption ratio (SAR) were determined. Based on the obtained results, the WQI values ranged between 10.36 and 97.19. About $53.2 \%$ of the samples were unsuitable for irrigation. However, $\mathbf{1 2 . 8 \%}$ of samples may be suitable for the irrigation of soils without salinization problems. The remaining samples (34\%) showed an average of WQI values were $8.51,6.38$ and 19.15 within the low, moderate, and high restriction classes, respectively. WQI may be successfully used as a guideline for the decision-makers.
\end{abstract}

Keywords: Groundwater Assessment, Water Quality Index, Agricultural Expansion Areas

\section{INTRODUCTION}

Groundwater that lies beneath the surface is one of the most important resources available to humanity, and it is an essential part of the hydrologic cycle. As the rapidly increasing population, several environmental problems are created, including groundwater quality deterioration (Christophoridis et al., 2009; Masoud et al., 2016). Therefore, it is more than necessary to provide a system that can assess its quantity and quality over space.

In groundwater studies, GIS and RS are ordinarily used for studies of different objectives related to groundwater. These include groundwater quality classification, and spatial analysis of groundwater quality (Asadi et al., 2007; Yammani, 2007).

Doneen (1964) and Christiansen et al. (1977) proposed different numbers of guidelines for irrigation water quality classifications. The broadest accepted criteria applied in many countries were adopted according to US Salinity Laboratory (Staff, 1954) proposed guidelines that deal with four criteria, i.e., toxicity, permeability, salinity, and others. Consequently, the proposed guidelines were adjusted by
Ayers and Westcot (1985) and widely used to assess irrigation water quality. Although all the guidelines above came in handy, none was satisfied under variable field conditions. To overcome this problem, scientists employed a mathematical index by combining water quality parameters to generate arithmetic tool called water quality index (WQI).

Water Quality Index (WQI) is a technique for assessing the suitability of groundwater for alternative purposes. WQI highlighted water quality issues by the decision-makers (Katyal, 2011). Ten widely applied and accepted water quality variables water used for calculating WQI, (Horton, 1965). According to Water Quality, National and International Agencies, there are many indexes specific to each area region (Dao et al., 2020; Tyagi et al., 2020).

The present study was proposed to assess groundwater suitability for irrigation in the new reclaimed area in Sohag Governorate using WQI and map the groundwater quality throughout the study area. This is very useful for increasing the interaction between decision-makers and end-users, and agricultural investors by facilitating the data of whole groundwater quality.

\section{MATERIALS AND METHODS}

\section{The study location}

Sohag governorate (Fig. 1) covers a part of the Nile Valley, Egypt and extends from the northern side of Qena governorate at latitude $26^{\circ} 07^{\prime} \mathrm{N}$ to the southern side of Assiut governorate at latitude $26^{\circ} 57^{\prime} \mathrm{N}$. It is bounded between longitudes $31^{\circ} 20^{\prime}$ and $32^{\circ} 14^{\prime} \mathrm{E}$.

As stated by the Census estimation in 2018, the total population in Sohag city Governorate reached $5(10)^{6}$ people (Sayed, 2018). They represent about five percent of the Egyptian population. The area's economy depends chiefly on crop production, like, wheat, cotton, sugar cane, corn, sorghum, and others. The study area is generally characterized by hot summer and mild winter (Fig. 2 and 3)with low rainfall and high evaporation rate (Liu et al., 2015).

\footnotetext{
DOI: 10.21608/asejaiqjsae.2021.167128

${ }^{1}$ Soil and Water Department, Faculty of Agriculture, Sohag University, Egypt

${ }^{2}$ Soil and Water Department, Faculty of Agriculture, New Valley University, Egypt

Received March 2, 2021, Accepted, April 23, 2021.
} 


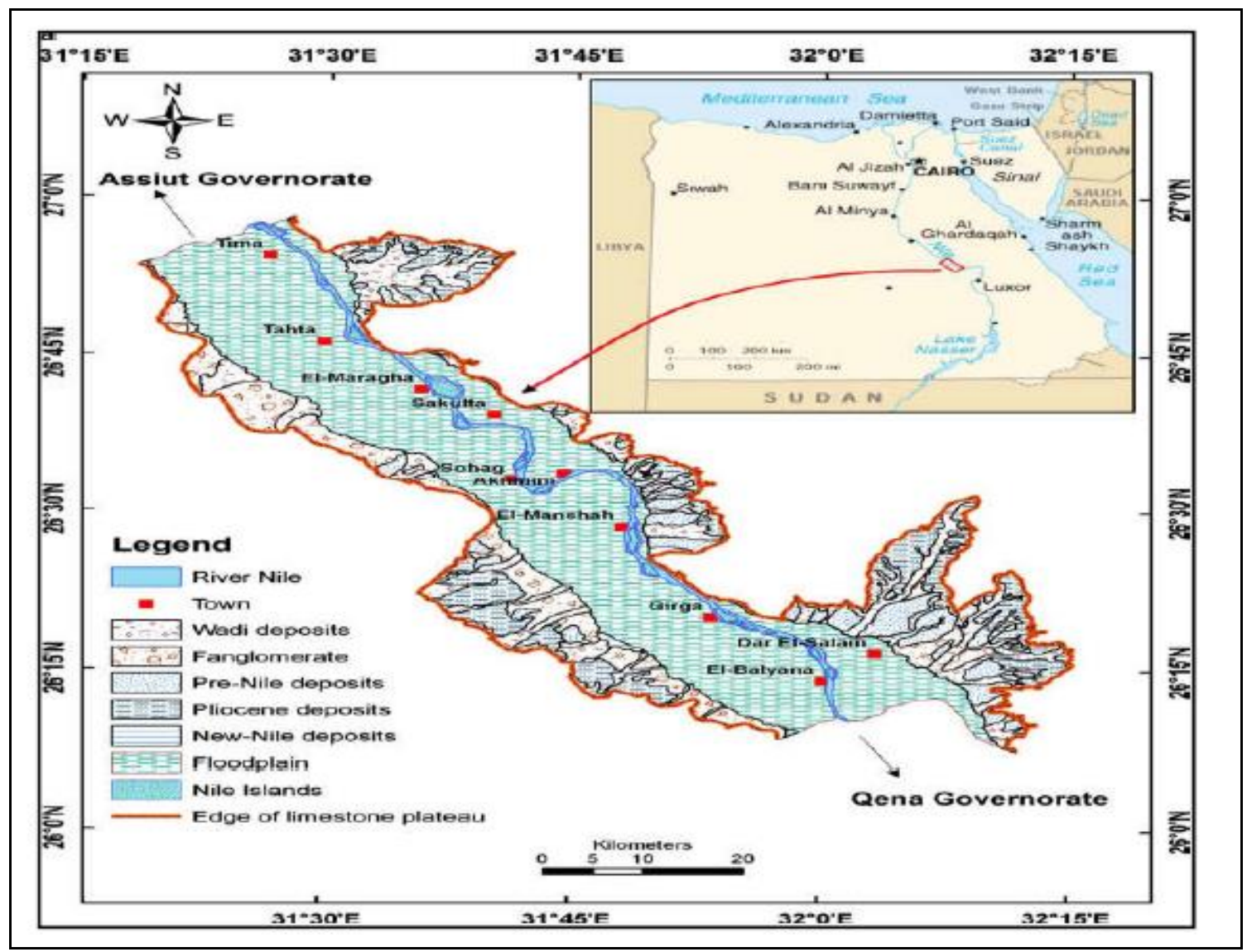

Fig. 1. The location map of the studied area.

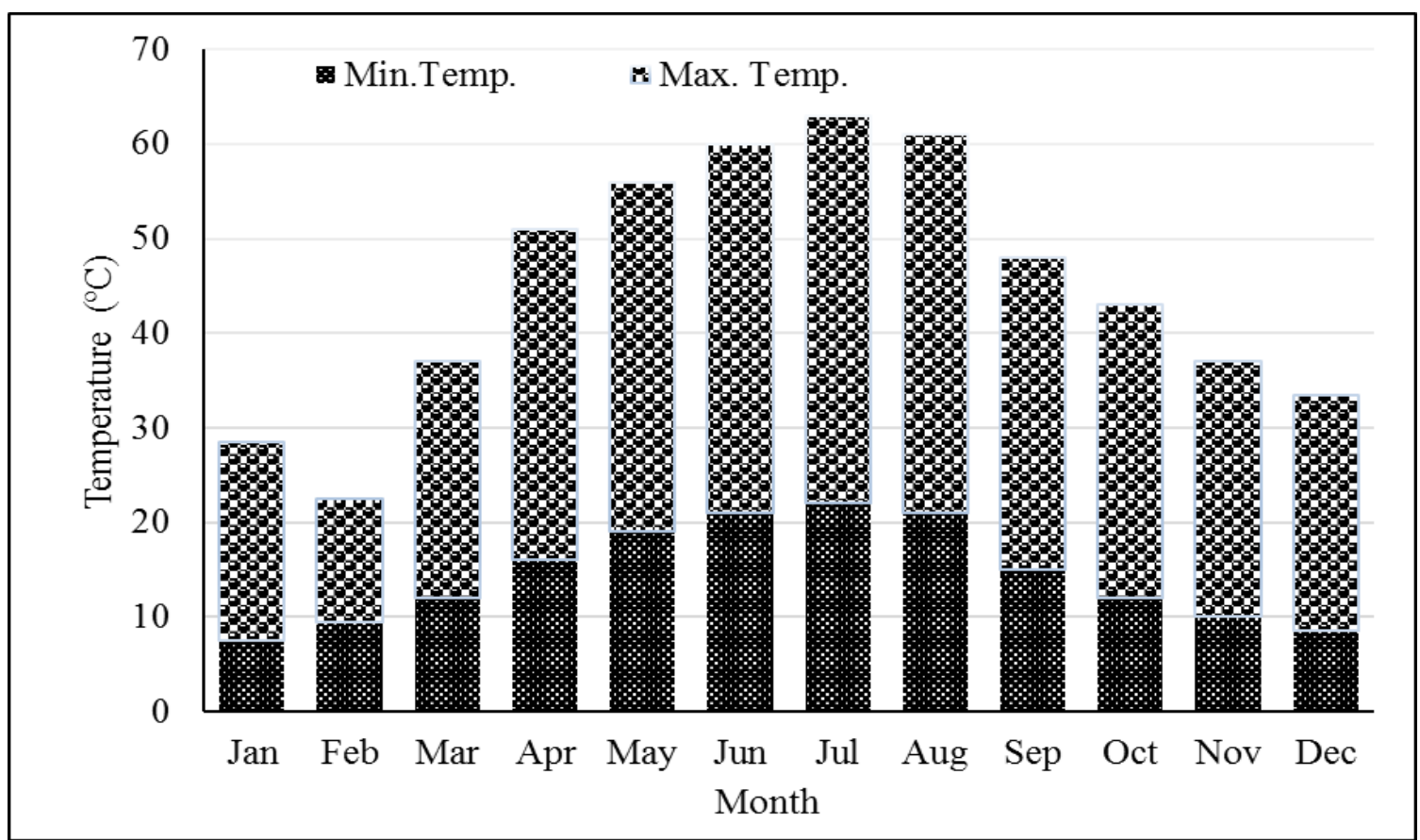

Fig. 2. The mean temperature of the study area. 


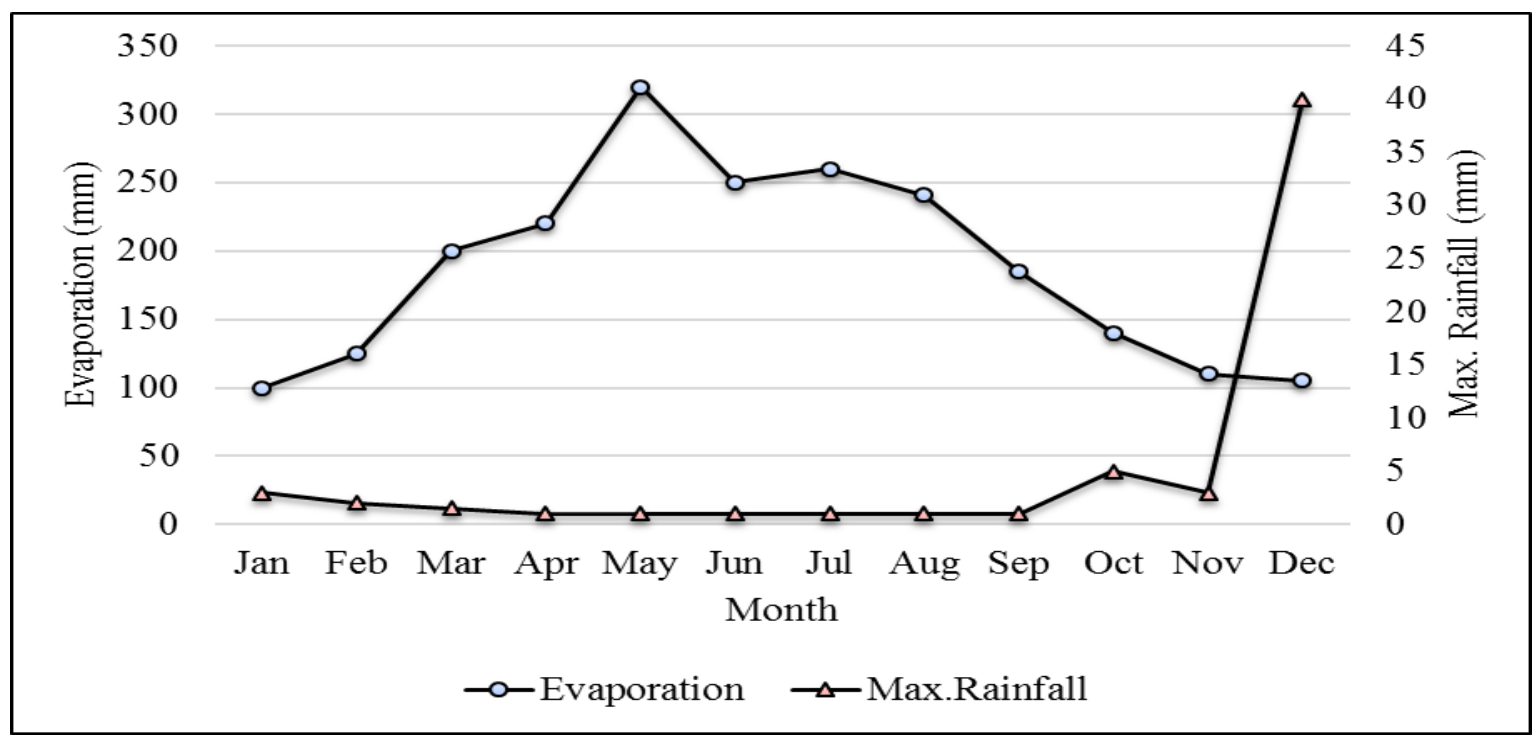

Fig. 3. The mean evaporation and rainfall of the study area.

\section{Satellite and ancillary data}

In the current study, the Landsat TIRS satellite data were used. The study area is covered by three images viz., (175 Path /42 Row, 176 Path /42 Row, and 176 Path /41 Row). The digital data of geo-coded cloud free of three images were downloaded from (http://glcf.umd.edu/data/landsat/). Using ENVI 4.8 software (Research Systems Inc., Boulder, CO, US), the Sohag Governorate image was extracted and masked from the whole image. The digital elevation model (DEM) and slope maps (Figs. 4 \& 5) of the study area were generated following the standard methodology of Mustafa and Moursy, ( 2020). The land use/ land cover map (Fig. 6) was also generated by El Sayed, (2016).

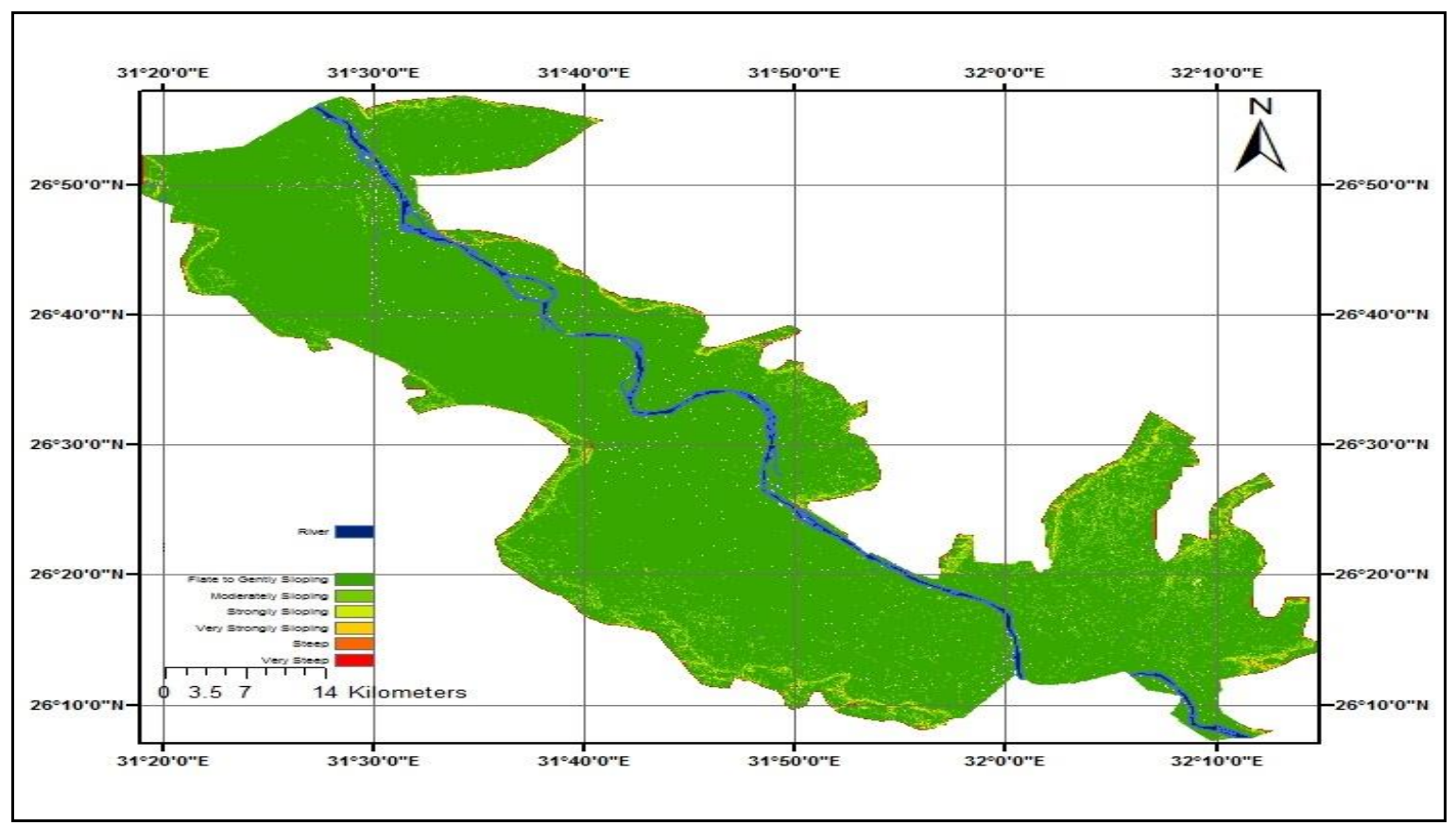

Fig. 4. The slope map of the study area. 


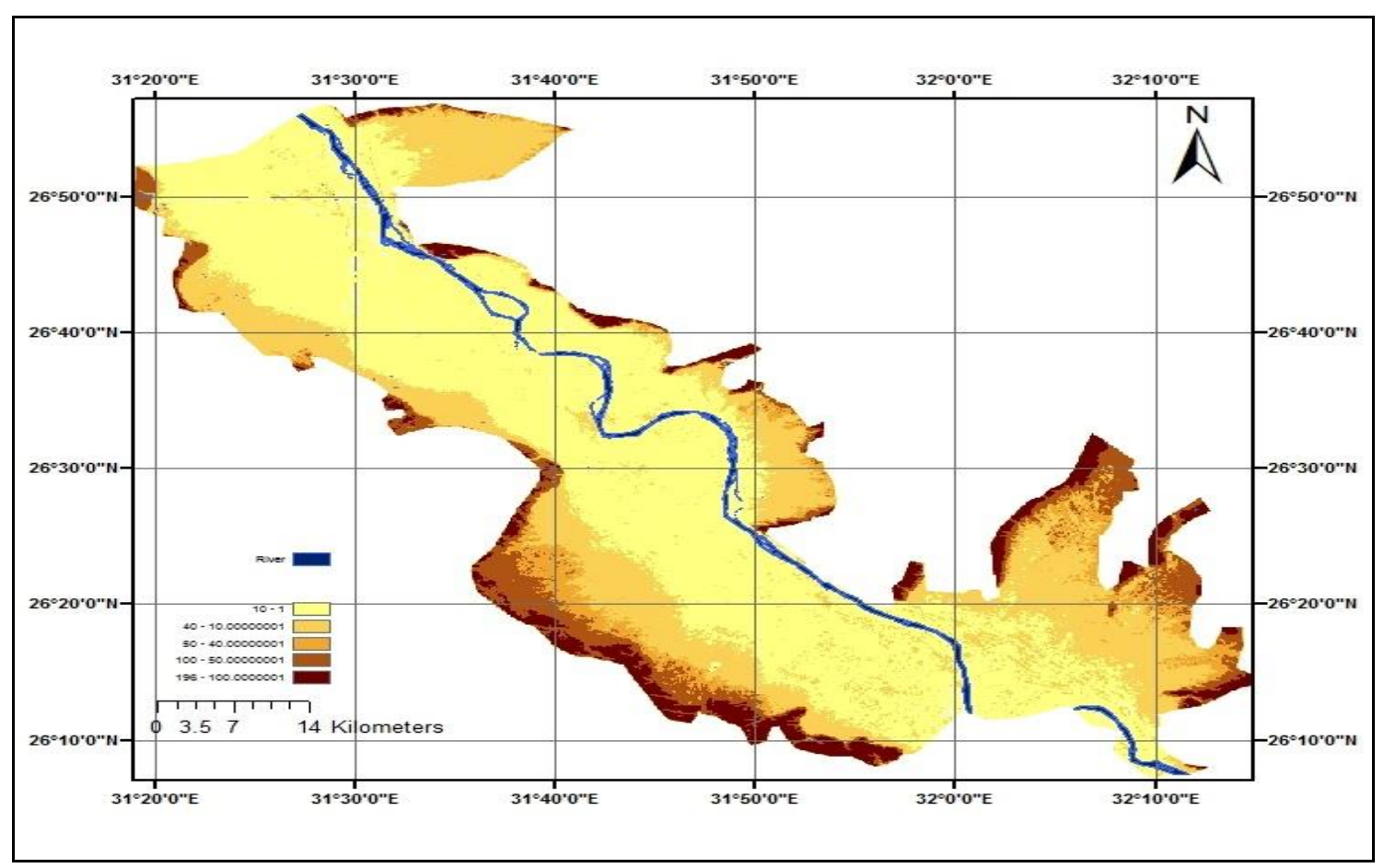

Fig. 5. The digital elevation model (DEM) map of the study area.

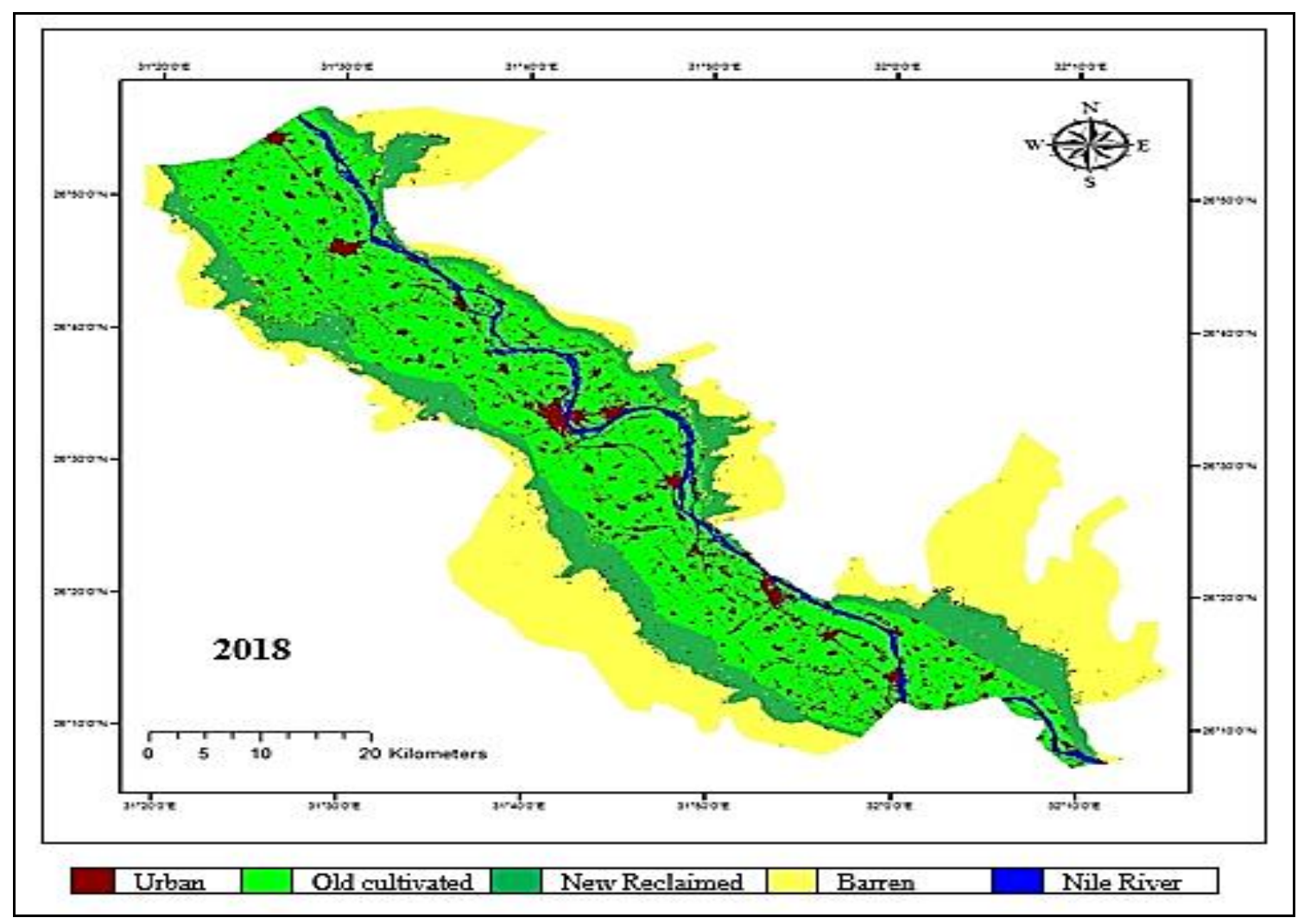

Fig. 6. Land use and land cover map of the study area. 
Available research papers, dissertations, and reports were a useful guide in the present study. Corresponding maps on a scale of 1:250,000 were used as secondary data to recognize the different features of the area under study.

\section{Methodology}

\subsection{Extraction of agricultural extension areas}

Using visual interpretation and unsupervised classification of ENVI 4.8 software (Research Systems Inc., Boulder, CO, US), the agricultural extension areas in the present study were extracted and masked out from the whole image. The extracted image was saved as a shapefile and used under Arc GIS 10.1 environment for the spatial data analysis.

\subsection{Field study and sample collection}

Forty seven water samples (Fig. 7) were collected to assess groundwater quality from the different wells located in agricultural extension areas according of the standard procedures proposed by Association et al., (1915).

\subsection{Water analysis}

The samples were filtered and stored for further analysis. All methods used in this study were done following standard methods of water chemical analysis elaborated (Association et al., 1915).

\section{Proposed water quality evaluation model}

The water quality index (WQI) proposed in this study was developed in two steps (Cude, 2001). Firstly, parameters that caused variability in irrigation water quality were recognized using (PCA/FA) as given in STATISTICA 10 Computer Program distributed by StatSoft Inc. Secondly, quality values (qi) and weights (Wi) were generated. Values of (qi) were estimated based on each parameter value, according to irrigation water quality parameters proposed by UCCC and by the criteria elaborated by Ayers and Westcot (1995). Each parameter weight used in the WQI was obtained from the PCA/FA, by the sum of all factors multiplied by each parameter's explainability. Then wi values were normalized such that their sum equals one. The water quality index was calculated, as shown in the following equation (Kawo and Karuppannan, 2018):

$W Q I=\sum_{i=1}^{n}\left(q_{i} W_{i}\right)$

Rating the classes based on the threat of salinity for soil and plants (Bernardo, 1995).

\section{Generation of thematic maps}

Inverse distance weight (IDW) interpolation determines cell values using a linearly weighted combination of a set of sample points. The weight is a function of inverse distance. Thematic maps were generated for each of the determined parameters using IDW interpolation in Arc GIS 10.1 software.

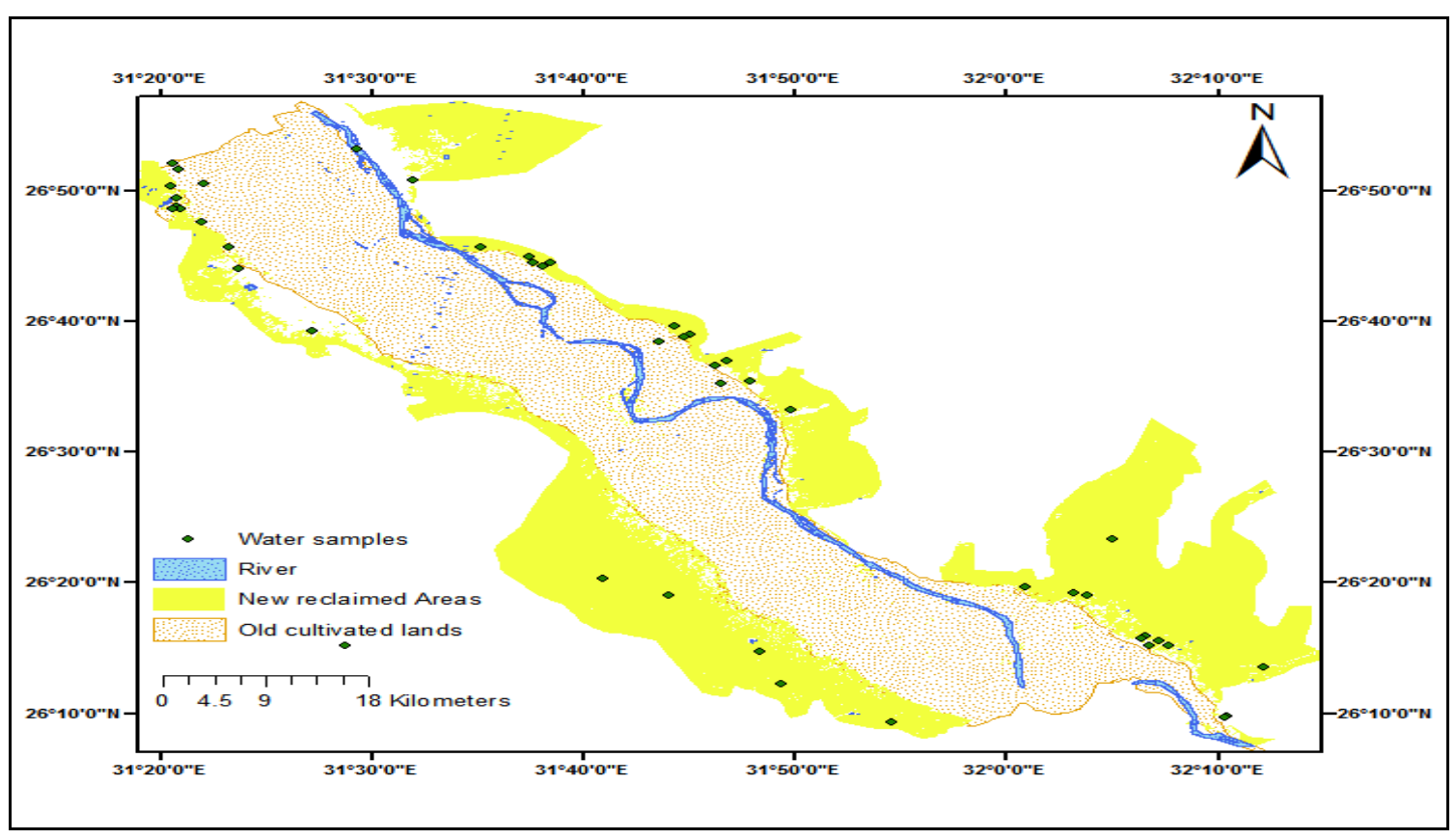

Fig. 7. Water samples locations map. 


\section{RESULTS AND DISCUSSION}

\section{Hydrochemical characteristics of groundwater samples:}

\subsection{Total dissolved solids}

The quality of irrigation water can vary depending on the type and quantity of dissolved salts. This salt accumulates in the root zone, and hence occurs the salinity problems cause a loss in yield. Irrigation water with TDS less than $500 \mathrm{mg} / \mathrm{L}$ is considered acceptable, whereas TDS greater than $2000 \mathrm{mg} / \mathrm{L}$ is harmful and unsuitable for irrigation (Sappa et al., 2014). In the current study, the lowest value of total dissolved solids was $476.3 \mathrm{mg} / \mathrm{L}$, while the highest value was 6094.2 $\mathrm{mg} / \mathrm{L}$, with an average value of $2129.91 \mathrm{mg} / \mathrm{L}$ (Table 1). More than $44 \%$ of samples are unfit for irrigation, and about $34 \%$ may adversely affect plant growth and hence requiring careful management practices.

\subsection{Hydrogen-ion activity}

The $\mathrm{pH}$ value represents the degree of acidity or alkalinity. It ranges from 7.9 and 8.5. This indicates that the groundwater is slightly alkaline to alkaline.

\subsection{Electrical conductivity}

In the present study, the electrical conductivity (EC) values ranged between 0.66 to $9.9 \mathrm{dSm}^{-1}$ with an average of $3.38 \mathrm{dSm}^{-1}$ (Table 2). The EC up to $0.7 \mathrm{dSm}^{-}$ ${ }^{1}$ has no effects; whereas, an EC of $0.7 \mathrm{dSm}^{-1}$ to $3 \mathrm{dS} / \mathrm{m}$ has a slightly moderate effect on crops. EC values of more than $3 \mathrm{dSm}^{-1}$ will damage the crop (AlKharabsheh, 1999; Ayers and Westcot, 1985). Water with high salinity is toxic to most plants and poses a salinity hazard. According to the EC values, the waters have been classified as excellent, suitable, permissible, doubtful, unsuitable (Table 2). 53.19\% of the studied when samples are unsuitable for irrigation. and $31.91 \%$ of samples exhibit permissible salinity levels these are suitable for irrigation and may leaching is required.

Table 1. Summary of descriptive statistics of determining chemical investigation of the groundwater samples.

\begin{tabular}{|c|c|c|c|c|c|c|c|c|c|}
\hline 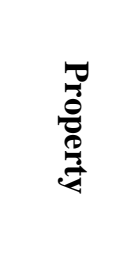 & $\begin{array}{l}\frac{3}{\mathbb{3}} \\
\stackrel{3}{=}\end{array}$ & 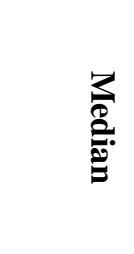 & 家 & 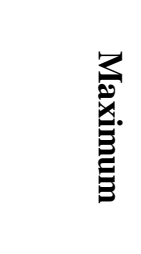 & 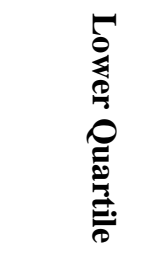 & 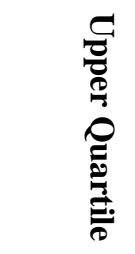 & $\frac{\mathscr{n}}{\mathfrak{2}}$ & 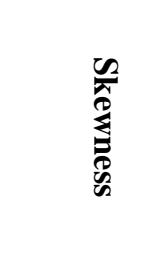 & 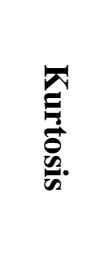 \\
\hline $\mathrm{Ec}$ & 3.38 & 3.07 & 0.66 & 9.90 & 1.76 & 4.55 & 9.24 & 2.10 & 0.93 \\
\hline $\mathrm{Na}^{+}$ & 20.69 & 19.87 & 4.34 & 67.69 & 8.73 & 28.26 & 63.34 & 13.18 & 1.26 \\
\hline $\mathrm{K}^{+}$ & 0.13 & 0.12 & 0.02 & 0.51 & 0.07 & 0.15 & 0.48 & 0.10 & 1.74 \\
\hline $\mathrm{Ca}^{2+}$ & 6.95 & 5.85 & 0.65 & 20.60 & 3.70 & 10.30 & 19.95 & 4.80 & 0.99 \\
\hline $\mathrm{Mg}^{2+}$ & 6.70 & 4.91 & 0.25 & 16.41 & 3.08 & 10.00 & 16.16 & 5.05 & 0.77 \\
\hline $\mathrm{HCO}_{3}^{-}$ & 4.41 & 4.32 & 1.80 & 9.67 & 3.73 & 4.91 & 7.86 & 1.30 & 1.31 \\
\hline $\mathrm{Cl}^{-}$ & 17.75 & 13.49 & 1.15 & 59.26 & 7.97 & 24.39 & 58.11 & 13.48 & 1.11 \\
\hline $\mathrm{SO}_{4}^{2-}$ & 10.941 & 10.18 & 0.27 & 30.58 & 3.68 & 17.08 & 30.31 & 7.76 & 0.44 \\
\hline SAR & 8.01 & 7.89 & 2.61 & 16.51 & 5.75 & 9.78 & 13.90 & 3.05 & 0.57 \\
\hline TDS & 2129.9 & 1941.56 & 476.28 & 6094.20 & 1145.08 & 2841.40 & 5617.92 & 1279.15 & 0.93 \\
\hline $\mathrm{pH}$ & 8.30 & 8.00 & 7.9 & 8.50 & 7.90 & 8.10 & 0.50 & 0.10 & -0.19 \\
\hline
\end{tabular}

Table 2. Classification of Irrigation water according to EC value.

\begin{tabular}{lccc}
\hline Class & $\begin{array}{c}\text { EC } \\
\left(\mathbf{d S m}^{-1}\right)\end{array}$ & Count & Samples within the limits \\
\cline { 3 - 4 } & $<0.25$ & - & \% \\
2 & $0.25-0.75$ & 2 & -- \\
3 & $0.75-2.25$ & 15 & 4.26 \\
4 & $2.25-3.00$ & 5 & 31.91 \\
5 & $>3.00$ & 25 & 10.64 \\
\hline
\end{tabular}




\subsection{Sodium adsorption ratio}

Sodium adsorption ratio (SAR) is an essential measure of alkali/sodium hazard to crops and damages the soil structure, making it compact and impervious (Subramani et al., 2005 Raju, 2006). The SAR is the relative proportion of sodium ions in a water sample to calcium and magnesium ions. The SAR values are classified into four classes (Table 3). In the present study, the water samples have low SAR values within 10 and hence less likely to cause any soil structure determination. This crucial result revealed that the grand water in the newly reclaimed area is most suitable for irrigation.

The chloride concentration of the groundwater samples was within a wide range of $1.15-59.26 \mathrm{me} / \mathrm{L}$. The range of $\mathrm{HCO}_{3}$ values in the water samples was 1.8 - $9.67 \mathrm{me} / \mathrm{L}$.

\subsection{Principal component and factorial model}

The correlation matrix for the measured parameters is presented in Table 4. The highest correlation above 0.9 was obtained between $\mathrm{EC}, \mathrm{Na}, \mathrm{Ca}, \mathrm{Mg}, \mathrm{Cl}, \mathrm{SAR}$, and TDS. According to the Kaiser-Meyer-Olkin (KMO) adequacy test, the value of 0.82 indicates that the model may be applied with any restrictions. These results are close to those reported previously (Parinet et al., 2004).

The result of many studies indicated that the two to four first generated components explain a high part of the variations of the original data (60 to $90 \%$ ), thus allowing the use of such components to describe the data completely (Helena, 2000; Inácio et al., 2002; Omran et al., 2014; Simeonov et al., 2003). According to Table 5, about $65.5 \%$ of the whole variance explained by the first Factor, whereas 11.4, 10.8, and 9.1\% were described by the second, third, and fourth factors, respectively. The $\mathrm{EC}, \mathrm{Na}^{+}, \mathrm{Mg}^{2+}, \mathrm{Ca}^{2+}, \mathrm{SO}^{2-}$ and $\mathrm{Cl}^{-}$ parameters present a load above 0.70 , whereas SAR presents a load of 0.63 in the first component.

\section{Water quality index characteristics}

The normalized weights wi were found to be 0.2961 , $0.2671,0.2982$, and 0.1386 for $\mathrm{EC}, \mathrm{Na}, \mathrm{Cl}$, SAR, respectively. Classes were defined according to the risk of toxicity to plants, salinity, and infiltration rate reduction (Holanda et al., 1997). Based on the results observed (Table 6), the WQI varied from 10.36 to 97.19. About $53.19 \%$ of samples unsuitable for irrigation and should be avoided for use under normal conditions. However, $12.77 \%$ and $8.51 \%$ of samples were very high and highly suitable for irrigation and may be used for a great extent of soils. The remaining samples showed an average of WQI within the moderate and margined suitable classes, with a percent of 6.38 and 19.15 , respectively. The spatial variability of WQI map is presented in Fig. 8.

Table 3. Classification of Irrigation water according to SAR value.

\begin{tabular}{lccc}
\hline \multirow{2}{*}{ Class } & SAR & \multicolumn{2}{c}{ samples within the limits } \\
\cline { 2 - 4 } & & Count & \% \\
\hline 1 & $<10$ & 36 & 78.26 \\
3 & $10-18$ & 10 & 21.74 \\
4 & $18-26$ & -- & -- \\
\hline
\end{tabular}

Table 4. Correlation coefficients of determining chemical investigation of the groundwater samples.

\begin{tabular}{lllllllllll}
\hline Property & $\mathbf{E C}$ & $\mathbf{N a}^{+}$ & $\mathbf{K}^{+}$ & $\mathbf{C a}^{2+}$ & $\mathbf{M g}^{2+}$ & $\mathbf{H C O}_{3}{ }^{-}$ & $\mathbf{C l}^{-}$ & $\mathbf{S O}_{4}{ }^{2-}$ & $\mathbf{S A R}$ & $\mathbf{T D S}$ \\
\hline $\mathrm{EC}$ & 1.00 & & & & & & & & & \\
$\mathrm{Na}^{+}$ & 0.97 & 1.00 & & & & & & & & \\
$\mathrm{~K}^{+}$ & 0.33 & 0.24 & 1.00 & & & & & & & \\
$\mathrm{Ca}^{2+}$ & 0.90 & 0.79 & 0.37 & 1.00 & & & & & & \\
$\mathrm{Mg}^{2+}$ & 0.90 & 0.80 & 0.43 & 0.86 & 1.00 & & & & & \\
$\mathrm{HCO}_{3}{ }^{-}$ & -0.21 & -0.13 & 0.04 & -0.30 & -0.24 & 1.00 & & & & \\
$\mathrm{Cl}^{-}$ & 0.97 & 0.91 & 0.28 & 0.92 & 0.92 & -0.30 & 1.00 & & & \\
$\mathrm{SO}_{4}{ }^{2-}$ & 0.93 & 0.93 & 0.34 & 0.79 & 0.78 & -0.15 & 0.82 & 1.00 & & \\
$\mathrm{SAR}^{2-}$ & 0.67 & 0.81 & 0.00 & 0.37 & 0.39 & 0.14 & 0.55 & 0.74 & 1.00 & \\
$\mathrm{TDS}$ & 1.00 & 0.97 & 0.33 & 0.90 & 0.90 & -0.21 & 0.97 & 0.93 & 0.67 & 1.00 \\
\hline
\end{tabular}


Table 5. Factors loads and communalities for the measured properties.

\begin{tabular}{lccccc}
\hline Property & Factor 1 & Factor 2 & Factor 3 & Factor 4 & Communality \\
\hline $\mathrm{EC}$ & 0.995 & 0.021 & 0.034 & -0.078 & 0.997 \\
$\mathrm{Na}^{+}$ & 0.949 & -0.040 & -0.039 & -0.284 & 0.985 \\
$\mathrm{~K}^{+}$ & 0.300 & -0.057 & 0.948 & 0.069 & 0.996 \\
$\mathrm{Ca}^{2+}$ & 0.922 & 0.117 & 0.085 & 0.240 & 0.928 \\
$\mathrm{Mg}^{2+}$ & 0.923 & 0.037 & 0.147 & 0.230 & 0.928 \\
$\mathrm{HCO}_{3}{ }^{-}$ & -0.197 & -0.975 & 0.054 & -0.084 & 0.999 \\
$\mathrm{Cl}^{-}$ & 0.978 & 0.093 & -0.032 & 0.085 & 0.973 \\
$\mathrm{SO}_{4}{ }^{2-}$ & 0.906 & 0.013 & 0.115 & -0.306 & 0.929 \\
$\mathrm{SAR}$ & 0.630 & -0.219 & -0.166 & -0.715 & 0.984 \\
Variance & 5.8958 & 1.0273 & 0.9739 & 0.8206 & 8.7177 \\
$\%$ variance & 65.5 & 11.4 & 10.8 & 9.1 & 96.9 \\
\hline
\end{tabular}

Table 6. Classification of water samples according to WQI.

\begin{tabular}{lcccc}
\hline Water Quality Class & \multirow{2}{*}{ WQI } & \multicolumn{2}{c}{ samples within the limits } & Suitability \\
\cline { 3 - 4 } & & Count & \% & \\
\hline Excellent & $85 \leq 100$ & 6 & 12.77 & Very high \\
Good & $70 \leq 85$ & 4 & 8.51 & highly \\
Poor & $55 \leq 70$ & 3 & 6.38 & Moderately \\
Very Poor & $40 \leq 55$ & 9 & 19.15 & Marginally \\
Unsuitable & $0 \leq 40$ & 25 & 53.19 & Unsuitable \\
\hline
\end{tabular}

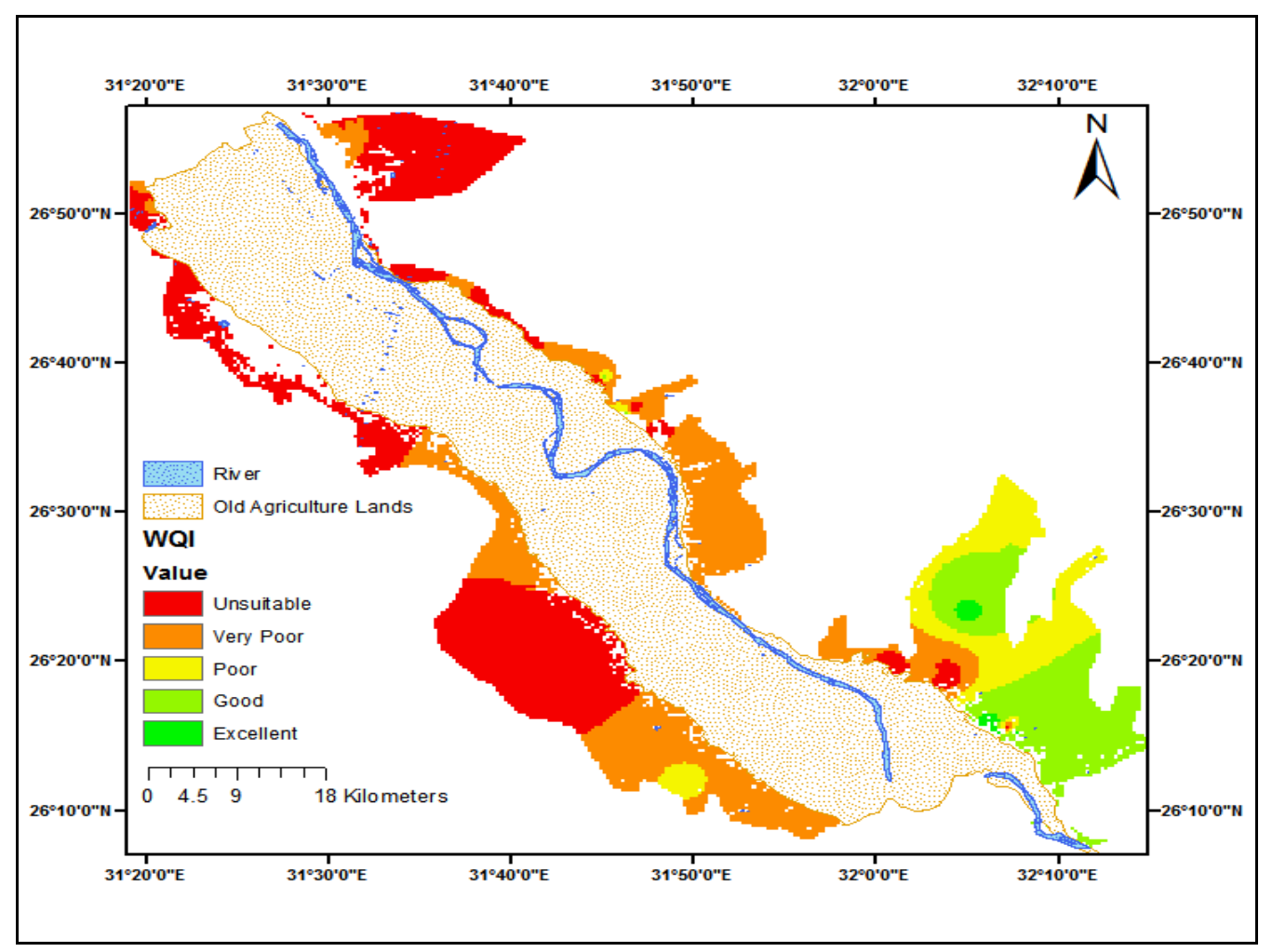

Fig. 8. The IDW of WQI values throughout the study area. 


\section{CONCLUSIONS}

The water quality index (WQI) considers as a tool for understanding ground water quality and management. It was calculated based on various important parameters in the studied area to dissect irrigation water's suitability for agricultural purposes. The observed data indicated that the WQI ranged between 10.36 and 97.19. About 53.19\% of samples unsuitable for irrigation and should be avoided use under normal conditions. However, 12.77 and $8.51 \%$ of samples were very high and highly suitable for irrigation and may be used for a great extent of soils. The remaining samples showed an average of WQI within the moderate and margined suitable classes, with a percent of 6.38 and 19.15 , respectively. WQI can be successfully used to transform the complex water quality data into easy and understandable guidelines appropriated by the decision-makers.

\section{REFERENCES}

Al-Kharabsheh, A.A. 1999. Influence of urbanization on water quality at Wadi Kufranja basin (Jordan). J. Arid Environ. 43:79-89.

Asadi, S., P.Vuppala and M.Reddy. 2007. Remote Sensing and GIS Techniques for Evaluation of Groundwater Quality in Municipal Corporation of Hyderabad (Zone-V), India. Int. J. Environ. Res. Public. Health. 4:45-52.

Association, A.P.H., A.W.W.Association, W.P.C. Federation and W.E.Federation. 1915. Standard methods for the examination of water and wastewater. American Public Health Association.

Ayers, R.S. and D.W.Westcot. 1985. Water quality for agriculture. Food and Agriculture Organization of the United Nations Rome.

Christiansen, J.E., L.S.Willardson and E.C.Olsen. 1977. Irrigation water quality evaluation. J. of the Irrigation and Drainage Division. 103:155-169.

Christophoridis, C., D.Dedepsidis and K.Fytianos. 2009. Occurrence and distribution of selected heavy metals in the surface sediments of Thermaikos Gulf, N. Greece. Assessment using pollution indicators. J. Hazard. Mater. 168:1082-1091.

Cude, C. 2001. Oregon Water Quality Index: A Tool for Evaluating Water Quality Management Effectiveness. JAWRA J. of the American Water Resources Association. 37:125-137.

Dao, V., W.Urban and S.B.Hazra. 2020. Introducing the modification of Canadian Water Quality Index. Groundwater for Sustainable Development. 11: 100457.

Doneen, L.D. 1964. Notes on water quality in agriculture. Department of Water Science and Engineering, University of California, Davis.
El Sayed, M. 2016. Integration of Remote Sensing \& GIS to Manage the Sustainable Development in the Nile Valley desert fringes of assiut-sohag governorates, upper Egypt. J. of the Indian Society of Remote Sensing. 44:759-774.

Helena, B. 2000. Temporal evolution of groundwater composition in an alluvial aquifer (Pisuerga River, Spain) by principal component analysis. Water Res. 34:807-816.

Holanda, J.d., J.d.Amorim, N. M. Ferreira, A.d.Holanda and F.d.S.Sá. 1997. Qualidade da água para irrigação. Manejo e controle da salinidade na agricultura irrigada. Campina Grande: UFPB. 137-169.

Horton, R.K. 1965. An index number system for rating water quality. J. of Water Pollution Control Federation. 37: 300306.

Inácio, P., T.Lewinsohn, R.L.d.Carmo and D.J.Hogan. 2002. Ordenação multivariada na ecologia e seu uso em ciências ambientais. Ambiente \& sociedade. 69-83.

Katyal, D. 2011. Water quality indices used for surface water vulnerability assessment. Int. J. Environ. Sci 2.

Kawo, N. and S.Karuppannan. 2018. Groundwater Quality Assessment Using Water Quality Index and GIS Technique in Modjo River Basin, Central Ethiopia. J. of African Earth Sci. 147:300-311.

Liu, F., X.Song, L.Yang, Y.Zhang, D.Han and H.Bu. 2015. Identifying the origin and geochemical evolution of groundwater using hydrochemistry and stable isotopes in the Subei Lake basin, Ordos energy base, Northwestern China. Hydrology and Earth System Sci. 19:551-565.

Masoud, A.A., K.Koike, H.A.Mashaly and F.Gergis. 2016. Spatio-temporal trends and change factors of groundwater quality in an arid area with peat rich aquifers: Emergence of water environmental problems in Tanta District, Egypt. J. Arid Environ. 124:360-376.

Mustafa, A. A. and Moursy, A. R.A. (2020). Integration of Geoinformatics and Ahp Model for Soil Site Suitability Analysis for The Major Crops in Sohag, Egypt. Int. J. of Recent Advances in Multidisciplinary Research, 7(5): 5784-5796.

Omran, E.-S.E., A.Ghallab, S.Selmy and A. A.Gad. 2014. Evaluation and mapping water wells suitability for irrigation using GIS in Darb El-Arbaein, South Western Desert, Egypt. Inter. J. Water Resour., Arid Environ. 3:6376.

Parinet, B., A.Lhote and B.Legube. 2004. Principal Component Analysis: An Appropriate Tool for Water Quality Evaluation and Management-Application to a Tropical Lake System. Ecol. Model. 178:295-311.

Raju, N.R. 2006. Seasonal evaluation of hydro-geochemical parameters using correlation and regression analysis. Curr Sci. 91(6):820-826.

Sappa, G., S.Ergul and F.Ferranti. 2014. Water quality assessment of carbonate aquifers in southern Latium region, Central Italy: a case study for irrigation and drinking purposes. Applied Water Sci. 4: 115-128. 
Sayed, H. 2018. Egypt's demographic opportunity: preliminary assessment based on 2017 census. Cairo: UNFPA/Egypt and CAPMAS.

Simeonov, V., J.A.Stratis, C.Samara, G. Zachariadis, D.Voutsa, A.Anthemidis, M.Sofoniou and T.Kouimtzis 2003. Assessment of the surface water quality in Northern Greece. Water Res. 37: 4119-4124.

Staff, U.S.L. 1954. Diagnosis and improvement of saline and alkali soils. Agriculture Handbook. 60: 83-100.
Subramani, T., L.Elango and S. R. Damodarasamy. 2005. Groundwater quality and its suitability for drinking and agricultural use in Chithar River Basin, Tamil Nadu, India. Environmental Geology. 47:1099-1110

Tyagi, S., B.Sharma, P.Singh and R.Dobhal. 2020. Water Quality Assessment in Terms of Water Quality Index. American J. of Water Resources. 1:34-38.

Yammani, S. 2007. Groundwater quality suitable zones identification: application of GIS, Chittoor area, Andhra Pradesh, India. Environmental Geology. 53:201-210.

\section{الملخص العربي}

\section{تقييم جودة المياه الجوفية باستخدام مؤشر جودة المياه في بعض مناطق التوسع الزراعي في محافظة سوهاح، مصر \\ عبد الرحمن عبد الواحد مصطفي، مهذى حسن حامد}

$$
\begin{aligned}
& \text { الحصول عليها، تراوحت قيم WQI بين بس. • و9 1.9V. } \\
& \text { حوالي r.ro\% من العينات كانت غير صالحة للري. ومع لرع } \\
& \text { ذلك، فإن ^.ب ٪ ٪ من العينات قد تكون مناسبة لري التربة } \\
& \text { دون مشاكل تمليحها. وأظهرت العينات المتبقية (ع \%٪) أن } \\
& \text { متوسط قيم WQI كان } 1.01 \text { و وس.7 و و } 19.1 \text { ضمن فئات } \\
& \text { الحصر المنخفضة والمتوسطة والعالية على التوالي. لذا } \\
& \text { يمكن استخدام WQI بنجاح كدليل لصانعي القرار. }
\end{aligned}
$$

تهدف الدراسة الحالية إلى تقييم جودة المياه الجوفية للأغراض الزراعية باستخدام مؤشر جودة المياه (WQI) في بعض مناطق التوسع الزراعي في محافظة سوهاج، مصر. حيث تم جمع سبعة واربعون ( مختلفة وتم تحليلها. أيضاً تم التعرف على القياسات التي تحدد جودة المياه باستخدام تحليل المكونات الرئيسية وتحليل العوامل (PCA / FA). وتم قياس التوصيل الكهربائي (EC) والصوديوم الذائب (Na) والكلوريد الذائب (Cl) ونسبة ادمصاص الصوديوم (SAR). بناءً على النتائج التي تم 